\title{
James McGill and the War of 1812
}

\section{by Stanley Brice Frost}

\begin{abstract}
James McGill was a man of many careers - courageous fur trader, successful Montreal merchant, conscientious city magistrate, influential member of the Legislative Assembly, senior member of the Governor's Executive Council, and finally Colonel and Acting Brigadier-General of Militia. Yet after his death, this outstanding personality quickly lapsed into obscurity. Except for having bequeathed land and endowment for a college, James McGill was forgotten. In the late 1920s, Maysie Steele MacSporran essayed a thesis-biography, but since it was never published her work remained largely unnoticed. In the 1980s S.B. Frost devoted the first chapter of his history of McGill University to its founder and John Cooper wrote a comprehensive entry in the Dictionary of Canadian Biography. Meanwhile, Lawrence Lande had gathered into his Canadiana collections valuable papers relating to McGill and his times, and the University's Rare Book Collections had acquired some survivors of his financial papers and correspondence. The McCord Museum also possesses artefacts, papers and portraits which illuminate the McGill years. The founding of the University Archives in 1962 made accessible many additional items of information. Benefitting from these and other new sources, Dr. Frost has now written a biography, which is to be published by the McGill-Queen's Press in the Spring of 1995. The last chapter has here been reworked to celebrate the 250th anniversary of James McGill's birth, 6 October, 1994.
\end{abstract}

James McGill a cumulé plusieurs mandats dont celui de courageux négociant en fourrures, de prospère commerçant montréalais, de magistrat consciencieux, de membre influent de l'Assemblée législative, de membre du Conseil exécutif du Gouverneur et enfin de Colonel et de Brigadier-général par intérim de la Milice. Aussi remarquable que fut sa personnalité, son décès l'a très vite plongé dans l'oubli et de son souvenir ne persistèrent que les terres et les fonds qu'il avait légués pour la création d'un collège. À la fin des années 1920, Maysie Steele MacSporran a écrit une thèse biographique sur James McGill mais comme celle-ci n'a jamais été publiée, elle est passée pratiquement inaperçue. Dans les années 1980, S.B. Frost a consacré le premier chapitre de son histoire de l'Université McGill à son fondateur et John Cooper lui a consacré un article complet dans le Dictionary of Canadian Biography. Parallèlement, Lawrence Lande réunissait pour sa collection Canadiana de précieux documents sur McGill et son époque, et la collection de livres rares de l'Université faisait l'acquisition d'un certain nombre de documents financiers et de lettres lui ayant appartenu. Le Musée McCord possède également des artefacts, des documents et des portraits des années McGill. La création des archives de l'Université en 1962 a donné accès à plusieurs documents. Grâce à ces derniers et à de nouvelles sources, S.B. Frost a rédigé une biographie qui sera publiée par les Presses universitaires McGill-Queen's au printemps 1995. Le dernier chapitre qui est publié dans ces pages a été réécrit en vue de célébrer le $250^{\circ}$ anniversaire de la naissance de James McGill, le 6 octobre 1994.

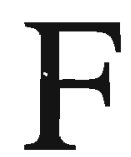
or the Canadians of the early 19th century, and particularly for the merchants of Montreal, the War of 1812 was as unwelcome as it was unnecessary. The immediate causes were straight forward and can be quickly recalled. Great Britain was striving to administer the coup de grace in its long-standing war with France, and had instituted a continental blockade of Europe - which created yet another complication for Montreal's fur trade, but one that had to be endured stoically. The resulting interference with ocean commerce, however, profoundly irritated the Americans, because it hampered their growing international carrier trade. ${ }^{1}$ In enforcing the blockade the Royal Navy assumed the right to stop and search neutral ships for contraband, and in so doing infuriated American captains by also claiming that some of their seamen were British subjects (as indeed they often were) and therefore liable to 'impressment', that is, forcible enrolment in the British Navy. From the American point of view this was nothing other than sheer piracy, and must be resisted at all costs. A belligerent party formed in the Congress, and after much talk the United States finally declared war on Great Britain and its dependencies. But as the 
Americans were not strong enough to challenge the Royal Navy at sea except in their own coastal waters, the only place where they could attack British possessions was on land, that is, along their own northern frontier. Consequently the Canadians suffered this 'War of 1812', even though it was none of their doing, or of their choosing.

The longer term implications of the war were, however, deeply disturbing. Many Americans were by no means unhappy with the turn of events. They had not forgotten the more northerly frontier line they had attempted to secure in the 1783 negotiations which had ended the War of Independence, and still hankered for at least the southern peninsula of Upper Canada to become part of the Union. It had been largely settled by former Americans, including not only zealous United Empire Loyalists but also many others who had come north simply in search of free land and lower taxes. Many politicians in the United States persuaded themselves that these Upper Canadians would warmly welcome a liberating army of their former neighbours and fellow-citizens: President (1800-08) Thomas Jefferson himself had remarked that apart from the citadel of Quebec the capture of Canada was 'a mere matter of marching'. Others were more imperially motivated. Richard Johnson from Kentucky, for example, declared in Congress that 'the waters of the St. Lawrence and the Mississippi interlock in a number of places, and the Great Disposer of Human Events intended these two rivers should belong to the same people', and John Harper of New Hampshire also anticipated the 'Manifest Destiny' doctrine when he said: 'To me, sir, it appears that the Author of Nature has marked our limits in the south by the Gulf of Mexico, and on the north by the regions of eternal frost'. Even Henry Clay, Speaker of the House of Representatives, wrote in 1813: 'It has ever been my opinion that if Canada is conquered it ought never to be surrendered if it can possibly be retained'. ${ }^{2}$ There can be little doubt that if Canada had succumbed to the American attack, the provinces would have been forcibly and permanently incorporated into the Union. If Canada was fighting reluctantly, she was nevertheless fighting for her life.

Because Upper Canada was the primary target, it was probable that the early activity in this war would take place on the Great Lakes and the Niagara
Peninsula. The attack on the St. Lawrence Valley, if and when it came, would equally probably be made as before on the pivotal point of the line - the city of Montreal. So believed James McGill, and mentally and physically he was by no means unprepared for such an assault.

By the year 1812 McGill had attained a position of primary responsibility in Montreal. For over thirty years a magistrate and twelve years a member of the Legislative Assembly, he was now the senior member of the Governor's Executive Council resident in the city, and therefore, in the absence of the Governor General and for lack of an elected mayor, he was de facto the head of civil authority. But he was also Colonel and Commanding Officer of the first battalion of the Montreal Militia. With the outbreak of war he was given two more militia companies and made commanding officer of the garrison of Montreal. Consequently, in this time of crisis, he was the head of both civil and military government in the city.

He was particularly well-positioned to have a good grasp of the military situation. Potentially the Americans vastly outnumbered the Canadians, and McGill knew that Sir George Prevost, the new Governor General and Commander in Chief of British forces in North America, watching a frontier that stretched from Halifax to the Great Lakes, would have to husband his resources with extreme care. The maritime provinces would not be in any immediate danger, because of the protection of the Royal Navy and the great difficulties in the way of land access, but the Americans were counting on Britain being so preoccupied with the struggle against Napoleon that she would not have regular army units to spare for the Canadas. In fact, in 1812 Prevost had 10,000 regulars under his command, but McGill knew from bis military sources that of these men, approximately 5,000 were in Nova Scotia, 4,000 in Lower Canada, but in the most threatened area, Upper Canada, not more than 1200. These last were under the command of Major General Isaac Brock, who was also the acting Administrator of the upper province.

But from his trading contacts McGill was also well aware that there were allies eager to support the British effort. The Indians on the American western frontiers had been given the 'treaty' of Greenville in 1795 , 
James McGill and the War of 1812

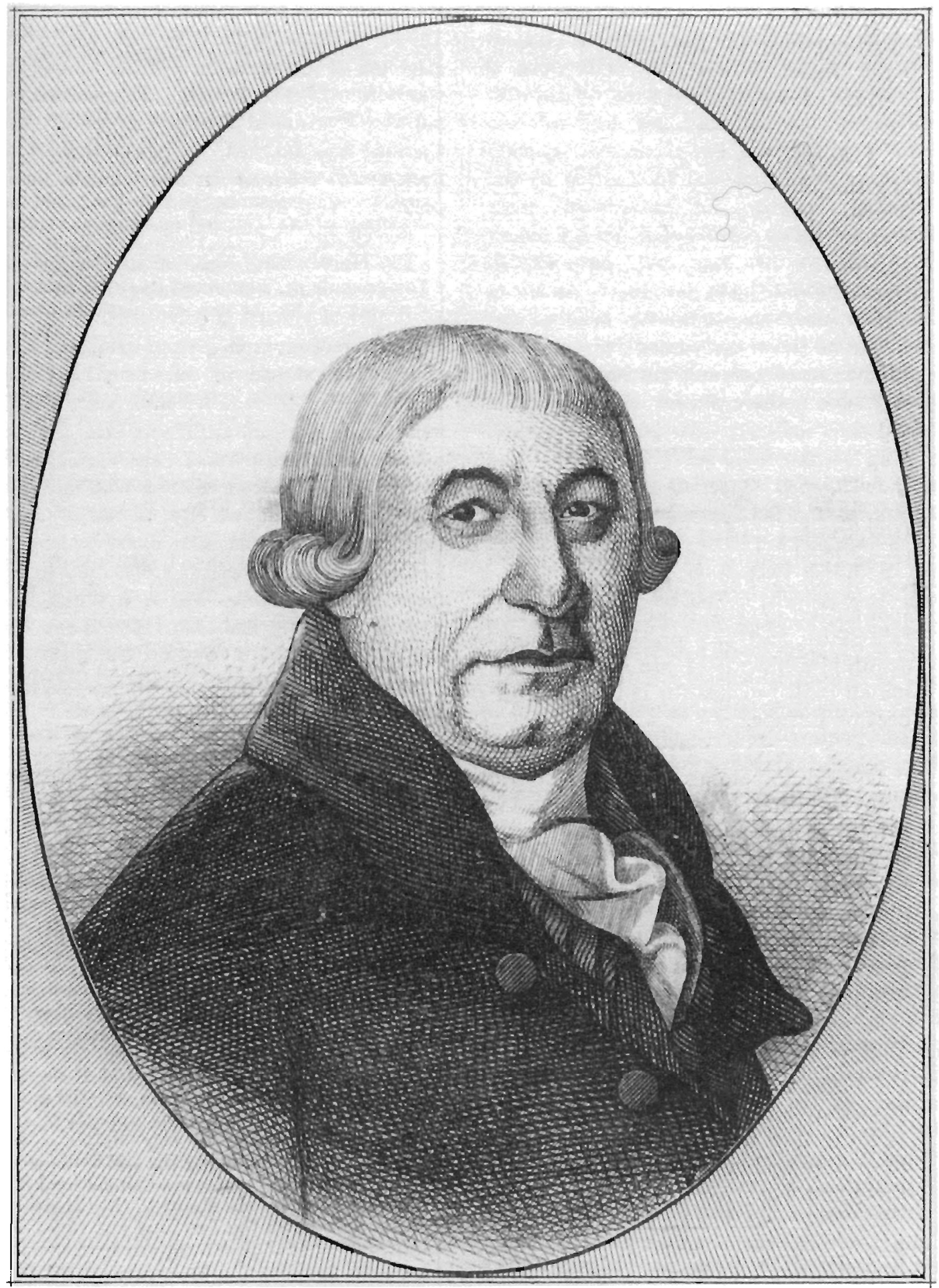

James McGill

Canadian Ilustrated News, May 29, 1875.

(Department of Rare Books and Special Collections) 
which had drawn lines between American and Indian territories, south of Lake Erie. They were told that all lands south and east of the line were to be open to American settlement, but all those to the north and west were to belong to the Indians. But inevitably the pressure of continued white settlement quickly overflowed these boundaries and Indians led by the Shawnee brothers, Tecumseh and Temskwatawa, were anxious for war to break out between the Americans and Great Britain so that they could have British support in their attacks upon the hated American settlements. The Americans, of course, believed that these Indian attacks were not caused by their own relentless encroachment westward, but were the result of deliberate British encouragement. Where did the Indians obtain their muskets, their powder and shot, other than from British traders out of Montreal? 'Who does not know', asked Governor Harrison of the Indiana Territories, 'that the tomahawk and the scalping knife of the savages are always employed as the instruments of British vengeance? At this moment... their agents are organizing a combination amongst the Indians within our limits for the purpose of assassination and murder'. ${ }^{3}$

There was considerable justice as well as rhetoric in these charges. Because the fur-trading partners of the North West Company, operating out of Montreal, were no more pleased with American settlement in the furbearing countries than were the Indians, they had readily sympathized with the natives and vigorously continued the Indian trade on which their fur supplies and the native way of life mutually depended. That commerce had always included weapons and ammunition, and continued to do so, so there was some justification for the American charges. But on the outbreak of war the Nor'Westers went further: they not only urged Prevost to employ Indians against the American invaders but they offered the services of their ships and men on the St. Lawrence and the Great Lakes, and also to provide stores at what they termed 'moderate prices' to the British Indian Department. ${ }^{4}$ These offers to McGill's great satisfaction were readily accepted. Since the incumbency of Governor General James Craig (1807-11) the administration had been quietly following a dual policy, one public and the other private. 'The salient features of both policies were to win the allegiance of the tribes by impressing upon them the wisdom of preserving a friendship with the
British in the face of American westward expansion'. The secret aspect of the policy was a generous flow of gifts and strong assurances of military support if war was declared. The British were not seeking a conflict but were determined to make full use of Indian allies if Canada were attacked, and the assistance of the fur traders was essential for the implementation of this policy.

The Nor'westers were, of course, James McGill's former associates and continuing friends. Although by 1810 he had himself largely retired from fur trading, and more recently from general trade, McGill continued to make good use of the merchants' informationnetwork. He had been for some years alarmed by the increasing American talk of war. His sympathies were naturally with the fur traders, and the Upper Canadians, but his immediate concern was with the forces of law and security in his own city, Montreal. He had vivid memories of the American occupation of the city in 1775 and he had no desire to repeat that experience. If there was again to be war with the Americans, his contribution to the defence of his country was to be in the preservation of civil peace and good order in the city, and in the organization and training of its garrison, the local militia.

These militia units were the third and largest part of the forces under Prevost's command, and if some were ill-equipped and poorly trained, there were others who were in a reasonable state of preparedness. In particular Prevost had good reason to be grateful to the local leaders in Montreal. To fill the gap left by the extinction of the French colonial obligation laid upon rentiers for military service at the call of their seigneurs, the Governor's Council had introduced in 1777 the first Canada Militia Act. By this ordinance, all males between the ages of 16 and 60 were liable for service in the militia of their parish. Failure to enrol invoked fines, and the withdrawal of privileges to keep firearms. Captains in each parish had to submit lists of militiamen, and to 'draw out' their companies on the last two Sundays of June and the first two in July, 'in order to inspect arms, fire at marks, and instruct them in their duties'. ${ }^{6}$ James McGill and other prominent merchants had given leadership in this matter for many years. In 1787 that old gossip Alexander Henry, who had been away from Montreal for some time, wrote to a friend: 'At my return here I found all our friends 
Militia Mad, James McGill is a Major and Isaac Todd a Captain and so is old Dobie'. mercantile sources of information, McGill was aware more than most of what was afoot in the United States, and because of those memories of 1775 he and his friends knew they had good reason to be serious about the militia. Consequently, they welcomed the Governor General's initiative, and responded readily when in 1790 he issued a call that all officers of the militia should urgently consider 'the proper means for putting the Militia under their Command in the most respectable Condition, that they may be able to defend themselves and the Province against all desultory or piratical attacks'. In 1794 James McGill was invited to address the Grand Jury empanelled at the Court of Quarter Sessions in Montreal and took the opportunity to dispel rumours that the militia would be sent abroad to fight wars in distant countries; but, he argued, to go to the assistance of their friends in Upper Canada, if they were attacked, would be only wise and prudent:

is there among us any men, so weak and inconsiderate as to say, we can defend our country when an enemy shall have entered it and no sooner? Shall we of the town say that when the enemy is at the gates of Montreal it will then be time enough to resort to arms? Or will the inhabitants of a neighbouring parish refuse to assist those, who from local situation may be exposed to inroads from an enemy, until they themselves are attacked in their houses? ${ }^{8}$

A bilingual manual was prepared entitled 'Rules and Regulations for the formation, exercise and movements of the Militia of Lower Canada', and while this compendium of military training was not published until May 1812, it shows the seriousness and thoroughness which had characterised militia training for many years. James McGill and his fellow officers, because of their long participation in the organization of the militia, were to prove an important part of Canada's resources when the war finally erupted.

McGill had shown his strong support for the imperial government in other and more direct ways. France declared war on Britain in 1793 and a year later, he was chairman of the Montreal Association, the purpose of which was to support British rule in Canada. In 1799 he joined a committee to receive and remit voluntary subscriptions to aid Britain in the prosecution of the war in Europe. ${ }^{9}$ The peace of 1801-3 brought some temporary respite, but with renewal of the conflict the news of Nelson's great victory at Trafalgar in 1805 was good news indeed: for Canada, Britain's command of the oceans was essential. The relieved and grateful merchants of Montreal raised in 1809 a monument to the fallen hero at the top of Jacques Cartier Square, a few yards from McGill's home, and he was a generous contributor.

But if Britain ruled the seas, the land war was by no means won, and the irritation to the Americans was if anything only increased. It was rather ironic that President Madison should sign in Philadelphia the declaration of war against Great Britain on the 18th of June, 1812, when Lord Castlereagh the new British foreign secretary had announced only two days earlier in London that the offending naval 'stop and search' Orders in Council were to be revoked. But the two men were thousands of miles apart, and were ignorant of each other's actions; it would be weeks and months before the news of either decision reached the ships on the high seas and the more distant frontiers. ${ }^{10}$ In Lower Canada, James McGill, alerted by his private sources, was the first to receive and send to the Governor General reliable information that the Provinces were at war. His letter was dated 24 June, 8 a.m. and was brief:

May it please your Excellency

I have just been informed by Mr. Richardson that he has learnt by an Express from Albany that war has been declared against Great Britain by the American States, and as an Express is going from this [city] to Quebec I hold it to be my duty to give you this Information.

I shall immediately call a meeting of the Executive Councillors ... ${ }^{11}$

McGill signed himself 'Chairman of a Committee of the Executive Council', and it is clear that he was acting in accordance with earlier planning. The immediate tasks were to mobilize the militia, to decide what to do about United States citizens who were currently present in Montreal, whether immediately to impose martial law, and finally what to do about trading relations with the enemy. McGill's correspondence over the next few days and weeks 
reveal him and his colleagues grappling with the practicalities of the situation. His fellow councillors in these anxious days were old collaborators in public affairs, Chief Justice James Monk and Judge Pierre Louis Panet, and it is obvious that there was unanimity among them; all three were well known as strong supporters of the Crown. The order for mobilisation of the militia was straightway promulgated in the city, and dispatched to the captains of units in the surrounding parishes. Proclamations were also posted that all American citizens must depart the city within a week 'on pain of arrest'. It was decided that for the present it was not necessary to proclaim martial law. When a few weeks later, it was decided that this step had become prudent, the Committee nevertheless recommended that the civil courts should continue until further notice to deal with cases of a purely civil nature.

The question of trade was a more difficult matter. An embargo was placed on the export of articles likely to be of use to the enemy forces, such as arms, ammunition, horse harnesses, blankets, woollens and scalping knives; and a customs check-point was established at the half-way house on the road between La Prairie and St. John on the Richelieu River to enforce these regulations. But merchant that he was, McGill saw no reason for Americans who wanted to continue honest commerce with Canada to be prevented from doing so, especially those bringing in food supplies or valuable export commodities such as lumber or potash. Trade of this kind was to be allowed, but regulated by the granting of licences. Also, the petitions of those Americans who asked to be permitted to continue their residence in Montreal were to be scrutinized leniently: 'in all doubtful cases', McGill reported to Prevost, "we are inclined to Indulgence rather than Rigour, being of opinion that such are the Intentions of the Governor in Chief'. They were further encouraged in this practice, McGill remarks, because, if newspaper reports were to be believed, the United States authorities were behaving with reciprocal 'indulgence'.

The fact was that enthusiasm for this war was not widespread among the general American population, especially in those States which normally traded freely with the Canadas. Many Vermont and New York farmers saw lucrative opportunities in the need of the
British forces to be supplied with grain and cattle. A clerk in the Army commissariat was assigned particularly to oversee the busy trade in beef from Vermont; at Ogdensburg, New York, a constant flow of supplies, mostly cattle and sheep, moved across the St. Lawrence to Fort Wellington. When the American commander stationed at Ogdensburg raided Gananoque across the river, and provoked a retaliatory raid by 'Red George' Macdonell and the Glengarry Light Infantry, compelling the American forces to retreat to Sackets Harbor, the citizens of Ogdensburg petitioned that their troops should not return - military activities were obviously not good for business. ${ }^{12}$ However, once war had been declared, raids, skirmishes, even set battles could take place; men could be killed, homes could be burned, farms destroyed, women and children massacred. All these tragedies did indeed take place.

Nevertheless, one of the decisions McGill found less difficult concerned the trader named Robert Dickson. He was probably the most influential trader amongst the western Indians of the upper Mississippi region. ${ }^{13}$ In the past, McGill had been one of his chief suppliers, and indeed had encountered much difficulty in collecting payments from him. Recently Dickson had been busy on his own initiative distributing presents among the Indians, in the name of their Great Father, the King of England, in order to consolidate their allegiance. Now he was putting in a claim to the Army paymaster for reimbursement. This was clearly a military matter, and was referred as a matter of course to General de Rottenburg, who in mid-July had been assigned over-all command of the Montreal district. But Dickson's activities had been, at least ostensibly, in accord with the fur trade's normal patterns and Rottenburg had been instructed to consult on all commercial matters with McGill. McGill had, in fact, already written to Prevost the previous month, urging the full use of the traders' services. It is not surprising then that it was decided that Dickson's services were of 'enormous value' and that he should be both reimbursed and strongly encouraged in his activities.

McGill's greatest concern, however, continued to be the preparation of the Montreal militia. MacSporran has transcribed his military correspondence for the years 1812-1813; the letters show that he worked continuously to keep his forces officered, disciplined and equipped. Shortly before the declaration of war, de 
Rottenburg, at that time also acting Administrator of Lower Canada, ordered the militia officers of the province to consider the best means of mobilizing the contingents. In Montreal, McGill was chairman of the officers' conference and was responsible for drafting its report. On 14 June he presented a scheme for dividing the men on the parish rolls into four groups by age: $16-18,18-30,30-40,40-60$. For the present, drill for six hours weekly should at once be arranged for the second and third groups, and the men readied to march at short notice; these would be the 'embodied' militia. The other two groups could remain in reserve, and form the 'sedentary' militia. Arms should be stored in each parish, possibly in the presbyteries - a central, recognized location, yet not profaning the sanctuaries themselves.

As soon as the American declaration of war became known, McGill sought, in accordance with this planning, to assemble the 'embodied' militia, more closely defined as the unmarried men, aged 18-25. They were to be enrolled for ninety days, or in the event of armed invasion for one year. Their companies would be attached to and work with the regular forces, but militia men were not to be forced to enrol in regular British army units. The Legislative Assembly of Lower Canada had enacted these terms in February, 1812 , so McGill had full authority for his call to arms. Mobilization went smoothly enough, he reported to the Governor General, except for resistance 'by a great number of the Inhabitants of this Island from the West End of the Parish of LaChine up to the End [of the Island].' Fifty nine men were called from the area, of whom only twenty eight responded by crossing over to Laprairie, where the troops were being assembled, and of these, four later changed their minds and returned home. In a report dated $1 \mathrm{July,} \mathrm{McGill} \mathrm{reported} \mathrm{these}$ matters to the Governor General and added that the revolt had spread to 'St. Geneviève behind Pointe Claire', where 'One of the unlawful assembly declared that they [were] determined upon and prepared for Civil War'. The Committee decided that the situation called for prompt action. A force was assembled for despatch the next morning. It consisted of 100 regulars, 200 militia and a detachment of artillery with two field guns. Clearly, McGill was taking no chances. Under the command of Captain John Richardson, 'about 350 men marched this morning before 7 o'clock consisting of English and Canadians nearly equal in number'.
The report of this incident was signed by James McGill, James Monk and Pierre Louis Panet, but MacSporran notes that the document is in McGill's handwriting. Evidently the language is also his own, and we notice its strong terms: those who oppose the constituted authorities are 'mad people' and are animated by a 'Spirit of disobedience and outrage'. McGill learns 'with astonishment' that they had confronted the King's troops. In response he was not prepared to be lenient or to appear indecisive. This was a war situation, with an enemy attack imminent. However, he was able to finish his report on a more positive note:

In communicating this unpleasant occurrence, we have much satisfaction in being able to assure your Excellency that the Militia went off [this morning] with great cheerfulness, and that from every Report we obtain there is Reason to believe that, except in the Parishes of Pointe Claire, Ste. Geneviève, and Ste. Anne, the greatest zeal prevails, and we are of opinion that the prompt measures which have been accepted, will put a stop to further disturbances. ${ }^{14}$

James McGill seems to have gauged the situation rightly, ${ }^{15}$ for three months later Alexander Henry wrote from Montreal to his friend John Askin, who lived in Sandwich, Upper Canada, in a most cheerful vein:

We are all soldiers here - I expect preferment [before] the Battle, being the oldest captain in the British Militia. The Americans on the opposite side of the river are continually attacking our Boats going up to Kingston, I think it is their intention (if they can) to stop the communication, which they will find a difficult matter to perform. We have near ten thousand men in arms here and can with ease raise twenty thousand more, in ten days in case they come over our lines - but we do not intend attacking them on their side - I hope the Cold weather will disperse them for the Winter, and before the Spring they may have a change in their Government, which will produce a peace...

Henry also mentioned that McGill's partner, Isaac Todd, was in the city and intending to stay the winter, so there was obviously no atmosphere of panic: "we 
are hourly expecting Genr. Dearboon [sic] with about Ten thousand of his troops to attack us, but we are not afeared of them, as our Canadians are in high Spirits'. ${ }^{16}$

One reason for the general mood of optimism at the time Henry was writing was the unusual event which had recently taken place in the city. Following General Brock's successful assault on Detroit, the American general William Hull and his army had surrendered and had been sent to Montreal as prisoners of war. This victory greatly boosted Canadian morale generally, and the carefully staged pageantry with which the Americans were received worked wonders for the local population. The Montreal Herald (for the city now had three newspapers ${ }^{17}$ ) gave a lively description of the reception given to the captured general and his troops:

\section{Montreal, September 12th.[1812]}

...General Hull and suite, accompanied by about twenty-five officers and three hundred and fifty solders, left Kingston under an escort of 130 men... At Lachine Captains Richardson and Ogilvie, with their companies of Montreal militia and a company of the King's [Regiment] commanded by Captain Blackmore, formed the escort till they were met by Colonel Auldjo with the remainder of the flank companies of the militia, upon which Captain Blackmore's Company fell out ... leaving the prisoners to be guarded [as they marched through the illuminated streets] by the Montreal militia alone... ${ }^{18}$

This initial success was indeed heartening, but it was only that - an initial success. Everyone in Montreal knew that this was not going to be the end of the war and that probably hard fighting lay ahead. Largely owing to the bravery of Tecumseh and his warriors, the Upper Canadians won another important but costly victory in the battle of Queenston Heights on 13 October, 1812; they suffered many casualties and lost their outstanding leader, General Isaac Brock. But the enemy suffered even greater losses and was forced to retreat across the river to their own side of the frontier. So the first attack on Upper Canada failed, but for the next twelve months American attacks and Canadian repulses continued. York (Toronto) was burned, but the invaders were cleared from the Niagara peninsula; the British lost an important naval engagement in Putin-Bay on Lake Erie, and the Upper Canadians were defeated in an engagement at Moraviantown on the banks of the Thames River. But the Americans could not capitalize on their successes because their troops wanted to return home in time for the harvest.

Altogether, from one summer to the next, 1812-13 was an indecisive year, but from Montreal's point of view, it was an opportunity for de Rottenburg and his regulars, and McGill and his militia, to prepare themselves even more thoroughly for the impending assault upon the city. It was a matter of considerable satisfaction to McGill at this anxious time that the defenders of the city were truly representative of the whole population, both Canadien and British. There were regiments like the Canadian Fencibles which were mainly English speaking and others like the Voltigueurs mostly French-speaking, and there were the embodied and sedentary militia units drawn from both communities, and officered by Canadien or British citizens without distinction. McGill could echo Henry with fervour: 'We are all soldiers here'.

The Americans did not begin their approach to the city until the fall of 1813 . Their plan was to employ a two-fold strategy. General Wade Hampton would follow the Lake Champlain-Richelieu route and attack from the south, and General James Wilkinson would advance down the St. Lawrence to attack the city from the west. Fortunately for the Canadians, the two commanders were mutually jealous and each suspected that in the event of failure the other would attempt to make him the scapegoat. The two invading forces, their every move reported by Indian scouts, slowly and cautiously manoeuvred into position. Hampton, making his way north following the Richelieu river, crossed into Canada as far as LaColle, but then changed his mind, retreated to Chazy and started out again by way of Four Corners, and from there proceeded down the Chateauguay River. He finally reached Chateauguay itself to the southwest of Montreal on 25 October. Wilkinson was even more tardy. His army and its boats had not left Sackets Harbor on Lake Ontario until 13 October, and he was still making his way down the St. Lawrence, the northern bank of which remained in Canadian hands.

Montreal readied itself to resist the attack. There would be no bloodless surrender as in 1775 . Church bells were rung, and beacons lighted to spread the news 
of the impending danger; all sedentary militia were to report to their captains, even if only armed with axes and spades. James McGill was raised to the acting rank of Brigadier General and given command of all the militia forces of the city, a striking confirmation of the respect he had won from de Rottenburg and Sir George Prevost. To borrow Milton's phrase, he was now in Montreal 'our Chief of Men'.

When news reached Montreal that Wilkinson's boats had successfully passed Prescott, Lt. Colonel Hercules Scott and the 103rd regiment of regulars were sent with Indian support from Caughnawaga (Kahnawake) to strengthen Lt. Colonel Louis-Joseph Deschambault and the Beauharnois militia at Coteau du Lac, and regular troops under Major General de Watteville were sent to reinforce Lt. Colonel de Salaberry's militia companies at Chateauguay, facing Hampton's invasion. De Salaberry's other forces included two companies of his own Voltigueurs, a light company of the Canadian Fencibles, a company of militia from Boucherville and 'a handful of Indians'. The speed and efficiency with which the militias moved into their positions were especially commendable. William Dunlop, who served as an Asst. Surgeon in the British 89th regiment, and later became a noted Canadian author, wrote in his Recollections: 'We came up with several regiments of militia on their line of march. They had all a serviceable, effective appearance - had been pretty well drilled, and their arms, being direct from the Tower [of London], were in perfectly good order... 19 Colonel Duguid, in his History of the Canadian Grenadier Guards, made a comparable comment: 'The obvious ease with which [militia] companies moved and acted in this campaign calls for explanation. There can be no doubt that this resulted from 15 months of consistent training... 20

As Acting Brigadier General in command of Montreal's militia defence forces, McGill was kept closely informed on all this military planning, and was called upon to supply local knowledge of the city and its environs, as well as of the qualities of the various militia units and their leaders. Once de Rottenburg and his staff had formulated their plans, McGill passed many anxious days, keeping his men alert while waiting for news of the enemy's approach. He had the satisfaction of knowing that the morale of the population continued to be very high.
For the men of the Chateauguay and Boucherville miltias, their day of testing was to be 26 October, 1813. That was when Hampton finally mounted his attack on their positions on the banks of the Chateauguay River. The Canadiens were happy to be commanded by one of their own, Charles-Michel de Salaberry, who made expert use of his familiarity with the terrain. He had chosen and prepared his ground with great care, and his main lines stood firm behind hidden wooden barricades, and stoutly repelled the American attack. The skilful deployment of flanking militia, to harass the enemy's advance, their expertise in woods-warfare, and de Salaberry's example of personal bravery - he stood exposed on a tree-stump, so that he might be seen by all, encouraging his men were further major advantages favouring the Canadians. Hampton, mired in the swamp into which he had been decoyed, was unable to maintain his communications. In mud and forest the Americans suffered considerable losses and were forced to retreat, first to Four Corners, and from there to Plattsburg. It has been reliably reported that on the Canadian side only some 350 men were actively engaged in this battle which stopped the march of Hampton's 5,000 regulars, but the forward units were supported in depth by many times their own number, had they been needed. Nevertheless, the victory was truly a Canadian rather than a British achievement. It was warmly celebrated in Montreal and by none more unreservedly than James McGill.

But three weeks later, Wilkinson was still coming down the St. Lawrence. To better negotiate the Long Sault rapids, he crossed to the Canadian bank of the river. He was pursued and attacked by British and Canadian forces at Crysler's Farm near Morrisburg. His rearguard was so severely mauled that his main army had to move hastily down river to Cornwall. Fearing further costly attacks, the Americans decided to recross the river, and regroup on their own side at Fort Covington on the Salmon River. Here they learned of Hampton's withdrawal to Plattsburg, and this was enough to persuade them to abandon any further plans for the attack on Montreal. The excellent coordination of efforts in Lower and Upper Canada had proved effective. As George Stanley commented: 'What gave Crysler's Farm the appearance of a decisive battle was Hampton's inability to brush de Salaberry's militia aside at Chateauguay'. ${ }^{21}$ The grand assault on the central pivot of the long St Lawrence valley had been defeated before it could be properly mounted. 
When the early rumours were confirmed that Hampton was back in Plattsburg and Wilkinson in Fort Covington, Montreal could relax. For this city, the 'War of 1812' was as good as over. Reverting to his substantive rank, Colonel James McGill received a signal from de Rottenburg to stand his militia down and to send his well-deserving patriots back to their homes. $\mathrm{He}$ and his men could look back with great satisfaction on a job well done; he himself could rest assured he had discharged in full his responsibility for his beloved city. He gave the order for demobilization on 20th November. Four weeks later he fell sick and after a short illness died on the nineteenth day of December, 1813.

The fallen leader was escorted to his resting-place by an honour guard of his own militia, and despite inclement weather the cortege was followed 'by an immense concourse of citizens of all classes'. The Gazette published his obituary recalling his many services to city and province, and a handsome monument was erected over his grave. Yet within a few years his achievements and even his name were almost wholly forgotten: McGill Street was only one more place name among many. He was not alone in this. The Frobishers, William McGillivray, Alexander Henry, Simon McTavish (who clung for a while to remembrance as a ghostly legend), Alexander McKenzie, McGill's partner, Isaac Todd, are even now known only to the few as anything more than vague names.

That perhaps is not altogether surprising. The early fur traders as a group contributed little to the Montreal community; they either fared poorly and died in obscurity, or made their money and like Alexander McKenzie departed - in his case to Scotland to become a laird. A visitor to Montreal in the late 1830 s remarked that 'those who made their fortunes in the fur trade have nearly, if not all, passed away from the theatre of action, and their money seems to have vanished with them'.22 But James McGill was different. During his lifetime he gave richly by personal service to his city and province, and when he died he left his large fortune, including one very generous bequest to education, within the city he had chosen as his own. The only other fur trader to make a comparable contribution was John Richardson, the father of Canadian banking and the moving spirit in the founding of the Montreal General Hospital. But he was of a younger generation, he had McGill's example to inspire him, and he aroused as much antagonism as support for his efforts by his frankly partisan attitudes: he constantly urged les canadiens to 'become British'. One can understand why not everyone wanted to perpetuate his memory. McGill on the other hand had always a great respect for his francophone colleagues and neighbours. He spoke their language, married into one of their prominent families, shared many of Governor General Carleton's tolerant attitudes, was generous in his will to French Catholics and English Protestants alike, and left by far the greater part of his fortune to his Canadien heirs.

Ironically, it was this last generosity which contributed most to his speedy historical demise. The Desrivières family not only inherited the bulk of his fortune but they also inherited his personal possessions - his furniture, books and papers. But they contested the educational bequest, and for over twenty years conducted a bitter legal battle which took the supporters of McGill College through the law courts right up to the Privy Council in England, not once but twice. It was 1835 before the Desrivières handed over the last of the College endowment. Mrs. McGill and her two sons had long died, and in the animosity of the legal battle with the anglophone community, any kindly feelings remaining in the rest of the family for their Scottish Protestant benefactor had long since evaporated. The name McGill was not perpetuated in family baptisms after 1832. Within another generation the family had moved out to East Stansted and built the chateau Malmaison on the extensive lands they had inherited; later generations moved into Quebec City and became a much respected family of lawyers and bureaucrats. What McGill furniture, books and papers still remained were dispersed by the move, and all recollection of James McGill was effectively lost to the family memory. ${ }^{23}$

Similarly, in anglophone Montreal, there were no close friends left after McGill's passing to keep his memory green. None of the three McGill brothers had any children and James, although the eldest, outlived all his own generation. Had his adopted daughter, Charlotte Porteous, not died of consumption a year before his own passing, we might well have had a source of kindly reminiscence. Isaac Todd retired to 
Bath, England, and left no written memoirs - he had no legitimate offspring and his nephew Andrew Todd had predeceased him. Those who contended for the College - Archdeacon G.J. Mountain, lawyer Stephen Sewell, physician John Stephenson - had no personal memories of the man who had made their fight possible. So as a personality James McGill quickly passed out of memory; he remained only as a name.

But as we have seen in this account of his role in the War of 1812, he was in his day a man of great importance in the affairs of his chosen city, and the story of his life, as fully as it can now be recovered, is an essential part of an extremely important period in Canadian history. If no one else remembers, we who are the richest inheritors of his foresight, patriotism and beneficence should recall with gratitude the achievements of this good, effective and generous man, and take great pride in our first benefactor and only founder, James McGill.

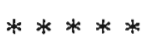

\section{Notes}

1. Because of the blockade, 'almost the whole of the carrying trade of Europe passed to American ships': G.F. Stanley, The War of 1812 (Ottawa: Canadian War Museum, 1983), 16.

2. Stanley, 31-32.

3. Cited R.S. Allen, His Majesty's Indian Allies, British Policy in the Defence of Canada, 1774-1815 (Toronto: Dundurn Press, 1992), 110.

4. Stanley, 65.

5. Allen, 112

6. A. Fortescue Duguid, History of the Canadian Grenadier Guards, 1760-1964 (Montreal: Gazette Printing Co., 1965), 7

7. Maysie S. MacSporran, "James McGill, A Critical Biographical Study", M.A. Thesis (McGill University, 1930), 209; citing 'Letters and Accounts of the North West Company', Toronto Public Library; 81.

8. Quebec Gazette, 24 July, 1794.

9. Myron Momryk, "Gray, Edward William", DCB V, 384.

10. News of Madison's declaration of war did not reach the American trading post Astoria on the Pacific coast until 15 January, 1813. Stanley, 162. McGill's own information, it should be noted, took a week to get from Philadelphia to Montreal and a further two days to reach Quebec City.

11. MacSporran, 214.

12. Stanley, 68, 228-230.

13. Allen, 125-164. It is noteworthy how far the activities of Montreal traders were reaching, far beyond the west bank of the Mississippi.

14. MacSporran, 215-220. 
15. This is further confirmed by a letter, dated 4 July 1812 , from E.B. Brennan, a secretary at 'Government House, Montreal' to the Chief Justice of Montreal, reporting that the militia had 'returned to a sense of their duty' and had promised full compliance with future orders, and adding that the 'the Magistrates' had consigned only two of their ringleaders to prison. PAC, RG 4, Al, Vol. 121.

16. M.M. Quaife, The John Askin Papers, II, 17961820 (Detroit: Detroit Library Commission, 1931), 734. Henry Dearborn was the American General in command at this time of the north-eastern front.

17. The Herald was first published less than a year earlier, 19 October 1811. It had been preceded by The Gazette and in 1807 by the Canadian Courant.

18. Montreal Herald, 12 Sept. 1812. See also W.H. Atherton, Montreal 1535 1914, (Montreal: S.J. Clarke Co., 1914), I, 117-8.

19. William Dunlop, Recollections of the American War of 1812-14, ed. A.H.U. Colquhoun. Toronto: Historical Publishing, 1905.

20. Duguid, 10.

21. Stanley, 265.

22. John McGregor, British America, 1839, a reference kindly supplied by Dr. E.A. Collard.

23. See especially W.D. Lighthall, "The newlydiscovered James and Andrew McGill Journal, 1797", Trans. Royal Society of Canada, Third Series, Section II, XXIX (1935), 43-50. 